\title{
Implementasi Akuntansi Berbasis Akrual Pada Pemerintah Daerah (Studi Pada Pemerintah Kota Semarang dan Pemerintah Kota Bandar Lampung)
}

\author{
Ulfi Maryati \\ Armel Yentifa \\ Wiwik Andriani \\ Jurusan Akuntansi Politeknik Negeri Padang
}

\begin{abstract}
The aim of this research is to evaluate implementation of Accrual based accounting of local government in Kota Semarang and Kota Bandar Lampung. The research finds that Government Act (PP) No. 71 Year 2010 as amendment of Section 36 ayat (1) Regulation No 17-2003 and Pasal 70 section (2) Regulation No.1-2004 has instructed government to apply Accrual accounting by the year 2008. However, the regulation for implementing this Accrual based accounting has just established since 2010 in PP 71-2010. The establishment of this governmental act, all governments both local and central, must apply Accrual based accounting by the year of 2015. The years from 2010 until 2014 can be identified as the transition from cash based accounting to Accrual based accounting. In December 2013, Central government has set Regulation of Internal Affairs Ministry (Permendagri) No. 64 in 2013 which can be identified as the regulation for controlling the implementation of PP 71 in 2010 at local governments. Local government of Kota Semarang is the only region in Indonesia which has applied Accrual based accounting since 2008. In 2013, government of Bandar Lampung start implementing this financial policy informally, but actually they still use PP 24-2005. This research was conducted using qualitative research methods with library research technique. The result of implementation accrual accounting in two public governments is appropriated to conceptual framework.
\end{abstract}

Keyword: implementation, Accrual, accountancy, local governments

\section{PENDAHULUAN}

Pemerintah sebagai pengelola keuangan masyarakat dituntut untuk mengelola keuangan secara transparan dan akuntabel. Akuntabilitas Publik di Indonesian dimulai sejak reformasi keuangan Negara yang ditandai dengan diterbitkannya UU No 22 Tahun 1999 tentang Pemerintahan Daerah, UU No 25 Tahun 1999 tentang Perimbangan Keuangan antara Pemerintah Pusat dan Daerah, PP No 105 Tahun 2000 tentang Pengelolaan dan Pertanggungjawaban Keuangan Daerah.

Pada masa 1974-1999, pencatatan transaksi keuangannya menggunakan metode tata buku tunggal berbasis kas (cash-based accounting). Bendaharawan mencatat setiap kas masuk dan kas keluar baik yang langsung melalui tangannya maupun perantara bank. Metode tata buku tunggal memiliki banyak kelemahan, misalnya sulit melakukan cross-check ketika melakukan pemeriksaan/perhitungan realisasi anggaran. Pasal 36 ayat (1) Undang-Undang Nomor 17 Tahun 2003 dan Pasal 70 ayat (2)
Undang-Undang No.1 Tahun 2004 yang mengamanatkan pemerintah paling lambat sudah menerapkan akuntansi Akrual (accrualbased accounting) pada tahun 2008.

Penerapan SAP Berbasis Akrual dapat dilaksanakan secara bertahap dari penerapan SAP Berbasis Kas Menuju Akrual (Cash Toward Accrual Basis) menjadi penerapan SAP Berbasis Akrual. Pemerintah menetapkan Peraturan Pemerintah (PP) 24 tahun 2005 Tentang standar Akuntansi Pemerintahan. Dengan keluar PP 24 tahun 2005, pemerintah menggunakan basis kas menuju akrual. Yang dimaksud dengan basis kas menuju akrual adalah pengakuan pendapatan, belanja, dan pembiayaan dalam Laporan Realisasi Anggaran menggunakan basis kas, sedangkan untuk pengakuan aktiva, kewajiban, dan ekuitas dalam Neraca menggunakan basis akrual.

Pada tanggal 22 Oktober 2010 pemerintah telah menerbitkan PP Nomor 71 Tahun 2010 tentang Standar Akuntansi Pemerintah berbasis Akrual. Terbitnya PP Nomor 71 
Tahun 2010, mengantikan PP Nomor 24 tahun 2005 mengenai hal sama. Walaupun sudah dinyatakan tidak berlaku secara substansial PP 24 Tahun 2005 masih dilaksanakan dalam rangka proses transisi penyusunan laporan keuangan paling lambat paling lambat sampai tahun 2014 karena pada tahun 2015 pemerintah pusat maupun pemerintah daerah harus menggunakan PP 71 tahun 2010. Menurut AB Triharta, dalam Suara Merdeka.com (2012), standar akuntansi pemerintah berbasis akrual merupakan standar akuntansi pemerintahan yang mengadopsi standar Akuntansi pemerintahan internasional (IPSAS). Standar ini, sudah digunakan di beberapa negara Amerika dan Eropa. Tapi di tingkat Asia Tenggara, baru Indonesia yang akan menerapkan.

Penerapan basis akrual pada akuntansi bertujuan untuk memperbaiki keterbatasan dan ketidakcukupan informasi yang disediakan oleh basis kas sehingga diharapkan dapat meningkatkan kualitas pengambilan keputusan (Mulyana, 2009). Basis Akrual adalah Suatu basis akuntansi dimana transaksi atau peristiwa ekonomi diakui, dicatat, dan disajikan dalam laporan keuangan pada saat terjadinya transaksi tersebut tanpa memperhatikan waktu kas diterima atau dibayar. Beban dan pendapatan secara hati-hati disamakan. Basis Akrual menyediakan informasi yang lebih handal dan terpercaya tentang seberapa besar suatu perusahaan mengeluarkan uang atau menerima uang dalam setiap bulannya. Pencatatan menggunakan metode ini mengakui beban pada saat transaski terjadi walaupun kas belum dibayarkan. Begitu pula dengan pendapatan. Pendapatan dicatat pada saat transaksi pendapatan terjadi walaupun kas atas transaksi pendapatan belum diterima.

Pada bulan Desember tahun 2013 Pemerintah menetapkan Peraturan Menteri Dalam Negeri (Permendagri) No. 64 tahun 2013 yang merupakan regulasi yang mengatur tentang implementasi PP 71 tahun 2010 pada Pemerintah Daerah. Pemerintah Daerah, Kota Semarang merupakan satu-satunya daerah di Indonesia yang sudah menerapkan akuntansi berbasis akrual sejak tahun 2005. Kemudian diikuti oleh Kota Sleman dan Kota Pontianak menerapkannya, Namun Kedua Pemerintah daerah ini mundur dan kembali menerapkannya PP 24 tahun 2010. Pemerintah Swiss melalui Swiss State Secretariat for Economic Affairs (SECO) memberikan apresiasi, dengan memberikan hibah kepada pemerintah kota Semarang untuk menyelenggarakan pendidikan dan pelatihan bagi daerah lain untuk persiapan implementasi PP 71 tahun 2010. Pada tahun 2013 pemerintah kota Bandar Lampung dan pemerintah kota Tanggerang juga sudah mulai menerapkannya. Penelitian ini bertujuan untuk mengevaluasi penerapan akuntansi berbasis akrual pada ketiga pemerintah daerah yang sudah menerapkan, yaitu pemerintah kota Semarang, Pemerintah kota Bandar Lampung

\section{METODE PENELITIAN}

Penelitian ini menggunakan pendekatan kualitatif deskriptif dan pengumpulan data dilakukan dengan wawancara mendalam, studi dokumentasi, dan studi lapangan.

\section{HASIL DAN PEMBAHASAN}

Implementasi Akuntansi Akrual di beberapa negara bervariasi. Hasil penelitian menunjukkan terdapat negara yang mengimplementasikan akuntansi akrual bersamaan dengan anggaran akrual, antara lain Selandia Baru, Australia, dan Inggris. Selain itu juga terdapat negara yang tidak atau belum mengimplementasikan anggaran akrual, diantaranya yaitu Amerika, Belanda, dan Indonesia (Oktaviani,2014). Penggunaan basis akrual merupakan salah satu ciri dari praktek manajemen keuangan pemerintahan modern, yang bertujuan untuk memberikan informasi keuangan pemerintah yang lebih transparan dan akuntabel dalam pengelolaan keuangan negara.

Perbedaan mendasar antara PP No. 24 tahun 2005 dengan PP 71 tahun 2010 antara lain:

1. Basis Akuntansi yang digunakan oleh PP 24 tahun 2005 adalah modifikasi basis kas (kas menuju akrual), dimana basis Kas digunakan untuk pengakuan pendapatan, belanja dan pembiayaan, serta basia akrual untuk pengakuan aset, kewajiban dan ekuitas di Neraca (PP 24 tahun 2005, par 39). Sedangkan PP 71 tahun 2010 basis akuntansi yang digunakan adalah basis akrual untuk laporan finansial dan basis kas untuk laporan pelaksanaan anggaran, karena sistem penganggaran Indonesia masih menggunakan basis kas. Bila penyusunan anggaran menggunakan basis akrual, maka laporan pelaksanaan anggaran juga mengunakan basis akrual. (PP 71 tahun 2010, par 44)

2. Laporan Keuangan Pokok yang harus disusun oleh Pemerintah daerah terdiri 7 laporan keuangan yang terdiri dari laporan 
pelaksanaan anggaran yang terdiri dari Laporan Realisasi Anggaran dan Laporan Perubahan Saldo Anggaran Lebih. Serta Laporan Finansial yang terdiri dari Laporan Operasional, Laporan Perubahan Ekuitas, Neraca, Laporan Arus Kas serta Catatan atas Laporan Keuangan. Sedangkan berdasarkan PP 24 tahun 2005 laporan keuangan pokok yang harus disusun oleh pemerintah daerah hanya 4 laporan keuangan, yaitu Laporan Realisasi Anggaran, Neraca, Laporan Arus Kas serta Catatan atas Laporan Keuangan, sedangkan Laporan Operasional dan Laporan Perubahan Ekuitas bersifat opsional

3. PP 24 tahun 2005 belum mengatur mengenai penyusutan aset tetap sedangkan dalam PP 71 tahun 2010 mengatur tentang penyusutan aset tetap (Kerangka Konseptual PP 71 tahun 2010, par 46). Pengakuan Pendapatan Pendapatan menurut basis kas diakui pada saat kas diterima di Rekening Kas Umum Negara/Daerah atau oleh entitas pelaporan(PP 24 tahun 2005, par 88), sedangkan Pendapatan-LO diakui pada saat timbulnya hak atas pendapatan tersebut atau ada aliran masuk sumber daya ekonomi. Pendapatan-LRA diakui pada saat kas diterima di Rekening Kas Umum Negara/Daerah atau oleh entitas pelaporan (PP 71 tahun 2010, par 95)

4. Belanja menurut basis kas diakui pada saat terjadinya pengeluaran dari Rekening Kas Umum Negara/Daerah atau entitas pelaporan (PP 24 tahun 2005, par 89). Sedangkan Beban diakui pada saat timbulnya kewajiban, terjadinya konsumsi aset, atau terjadinya penurunan manfaat ekonomi atau potensi jasa. Belanja diakui berdasarkan terjadinya pengeluaran dari Rekening Kas Umum Negara/Daerah atau entitas pelaporan (PP 71 tahun 2010, par 96-97).

5. Pengukuran Unsur Laporan Keuangan berdasarkan PP 24 tahun 2005 menggunakan nilai perolehan historis. Aset dicatat sebesar pengeluaran kas dan setara kas atau sebesar nilai wajar dari imbalan yang diberikan untuk memperoleh aset tersebut sedangkan Kewajiban dicatat sebesar nilai nominal (PP 24 tahun 2005, par 90). Sedangkan berdasarkan PP 71 tahun 2010 Pengukuran Unsur Laporan Keuangan, Menggunakan nilai perolehan Historis. Aset dicatat sebesar pengeluaran/ penggunaan sumber daya ekonomi atau sebesar nilai wajar dari imbalan yang diberikan untuk memperoleh aset tersebut,
Kewajiban dicatat sebesar nilai wajar sumber daya ekonomi yang digunakan pemerintah untuk memenuhi kewajiban yang bersangkutan (PP 71 tahun 2010, par 98).

\section{Langkah Implementasi Standar Akuntansi Pemerintahan Berbasis Akrual}

Adapun langka-langkah implementasi Standar Akuntansi Pemerintahan Berbasis Akrual menurut Komite Standar Akuntansi Pemerintahan (KSAP) tahun 2008 adalah:

1. Menyusun bagan akun standar.

BAS menurut Pasal 3 huruf $c$ permendagri 64 tahun 2013 merupakan pedoman bagi pemerintah daerah dalam melakukan kodefikasi akun yang menggambarkan struktur laporan keuangan secara lengkap dirinci sebagai berikut:

a. level 1 (satu) menunjukkan kode akun;

b. level 2 (dua) menunjukkan kode kelompok;

c. level 3 (tiga) menunjukkan kode jenis;

d. level 4 (empat) menunjukkan kode obyek; dan

e. level 5 (lima) menunjukkan kode rincian obyek.

Kode akun sebagaimana dimaksud pada ayat (3) huruf a terdiri atas:

a. akun 1 (satu) menunjukkan aset;

b. akun 2 (dua) menunjukkan kewajiban;

c. akun 3 (tiga) menunjukkan ekuitas;

d. akun 4 (empat) menunjukkan pendapatan-LRA;

e. akun 5 (lima) menunjukkan belanja;

f. akun 6 (enam) menunjukkan transfer;

g. akun 7 (tujuh) menunjukkan pembiayaan;

h. akun 8 (delapan) menunjukkan pendapatan-LO; dan

i. akun 9 (sembilan) menunjukkan beban

2. Tetapkan kebijakan akuntansi. Kebijakan Akuntansi Penyusunan kebijakan akuntansi bukan copy and paste semata dari PSAP, tetapi memilih standar mana yang akan diterapkan. Sebagai misal, standar memberi kemungkinan pencatatan persediaan secara perpetual. Khusus untuk persediaan keperluan kantor entitas pelaporan yang bersangkutan dapat memilih pencatatan persediaan secara physical atau perpetual. Contoh kebijakan akuntansi laiinya adalah Penyusutan aset, pencadangan piutang tak tertagih, kapitalisasi belanja, dll.

3. Susun sistem akuntansi yang akan digunakan untuk membukukan transaksi. Perlu dipertimbangkan apakah sistem akuntansi akan dilaksanakan secara manual, ataukah secara terkomputerisasi 
menjadi Sistem Informasi Manajemen (SIM). Sistem akuntansi pada dasarnya berisikan jurnal standar untuk mencatat transaksi, baik transakasi anggaran maupun transaksi finansial.

4. Pilih strategi implementasi akuntansi berbasis akrual, Strategi implementasi ada 2:

a. Langsung Akrual

Tahun 2015 langsung menerapkan akuntansi berbasis akrual.

b. Paralel Run

i. Tahun 2015 akuntansi CTA paralel dgn Akrual, di mana CTA formal Akrual informal.

ii. Tahun 2015 akuntansi Akrual paralel dgn CTA, di mana Akrual formal CTA informal.

5. Melatih dan memotivasi pegawai akuntansi secara berkelanjutan.

Berikut ini akan kami uraikan implementasi akuntansi Akrual pada masing-masing pemerintah daerah yang sudah Menerapkannya akuntansi Akrual.

\section{Implementasi Akuntansi Akrual Pada Pemerintah Kota Semarang}

Pemerintah Kota Semarang, menjadi satusatunya pemerintah daerah yang menerapkan sistem akuntansi pemerintah berbasis akrual secara penuh. Bahkan sejak tahun 2005 (Suara Merdeka.com, 2012). Dalam mengimplementasikan Akuntansi Akrual pemerintah kota Semarang terlebih dahulu menbangun Bagan Akun Standar. Meskipun kebijakan Akuntansi kota Semarang ditetapkan sebelum permendagri 64 tahun 2013 ditetapkan yaitu, bagan akun standar kota semarang sudah sesuai dengan permendagri tersebut.

Pendapatan pada akuntansi akrual pada pemerintahan ada secara garis besar dibagi 2, yaitu pendapatan LO dan pendapatan LRA. Pendapatan LO adalah akun pendapatan yang digunakan untuk menyusun Laporan Operasional, sedangkan pendapatan LRA adalah pendapatan akun pendapatan yang digunakan untuk menyusun Laporan Realisasi Anggaran.

Kebijakan Akuntansi Pemerintah Kota Semarang untuk pengakuan pendapatan LRA adalah pada saat kas diterima di bendahara Umum Daerah, pendapatan LO diakui pada saat memiliki hak atas pendapatan. Pengukuran pendapatan dengan menganut azaz bruto. Berikut ini contoh pengakuan pendapatan LRA dan Pendapatan LO pada pemerintahan kota Semarang.

Tabel 1

Perbedaan Kebijakan Pendapatan LRA dan Pendapatan LO Pemkot Semarang

\begin{tabular}{|c|c|c|}
\hline URAIAN & $\begin{array}{l}\text { LRA } \\
\text { (Anggaran) }\end{array}$ & $\begin{array}{l}\text { LO } \\
\text { (Finansial) }\end{array}$ \\
\hline $\begin{array}{l}\text { Jika } \\
\text { langsung } \\
\text { dibayar } \\
\text { maka tidak } \\
\text { terjadi } \\
\text { piutang } \\
\text { \&Pendapat } \\
\text { an masuk } \\
\text { LRA }\end{array}$ & $\begin{array}{l}\text { Jurnal : } \\
\text { Silpa } \\
\text { Pendapatan } \\
\text { Pajak } \\
\text { Reklame }\end{array}$ & $\begin{array}{l}\text { Kas } \\
\text { Pendapatan } \\
\text { Pajak } \\
\text { Reklame }\end{array}$ \\
\hline $\begin{array}{l}\text { Jika tidak } \\
\text { dibayar } \\
\text { maka timbul } \\
\text { piutang }\end{array}$ & $\begin{array}{l}\text { Jurnal : } \\
\text { Tidak ada }\end{array}$ & $\begin{array}{l}\text { Piutang } \\
\text { Pendapatan } \\
\text { Pajak } \\
\text { Reklame }\end{array}$ \\
\hline
\end{tabular}

Belanja diakui pada saat terjadinya pengeluaran kas dari Rekening Kas Umum Daerah atau pada saat pertanggungjawaban atas pengeluaran tersebut disahkan oleh unit yang mempunyai fungsi perbendaharaan. Sedangkan Beban diakui pada saat Timbul kewajiban atau terjadi konsumsi aset atau terjadi penurunan manfaat ekonomi/potensi jasa. Belanja diukur dan dicatat berdasarkan Nominal yang dibayarkan. Sedangkan Beban diukur dan dicatat berdasarkan nilai perolehan/nilai sekarang kas yang dikeluarkan dan atau akan dikeluarkan. Berikut adalah contoh pengakuan belanja dan beban pada LRA dan LO

Tabel 2

Perbedaan Kebijakan Belanja pada LRA dan Beban pada LO Pemkot Semarang 


\begin{tabular}{|l|l|l|}
\hline URAIAN & $\begin{array}{l}\text { LRA } \\
\text { (Anggaran) }\end{array}$ & $\begin{array}{l}\text { LO } \\
\text { (Finansial) }\end{array}$ \\
\hline $\begin{array}{l}\text { Contoh: } \\
\begin{array}{l}\text { Pembelian } \\
\text { Rp.100.000 ATK }\end{array}\end{array}$ & $\begin{array}{l}\text { Pada saat } \\
\text { pembelian } \\
\text { Belanja } \\
\text { barang } \\
\text { Silpa }\end{array}$ & $\begin{array}{l}\text { Pada saat } \\
\text { pembelian } \\
\text { Beban persd } \\
\text { Kas }\end{array}$ \\
\hline $\begin{array}{l}\text { Akhir periode } \\
\text { stock opname } \\
\text { sisa Rp.30.000 } \\
\text { maka dilakukan } \\
\text { jurnal koreksi } \\
\text { mengurangi } \\
\text { beban sebesar }\end{array}$ & $\begin{array}{l}\text { Pada saat } \\
\text { mengakui } \\
\text { persediaan } \\
\text { akhir tahun: } \\
\text { dan nampak } \\
\text { pada } \\
\text { persediaan di } \\
\text { neraca }\end{array}$ & $\begin{array}{l}\text { Pada saat } \\
\text { mengakui } \\
\text { persediaan } \\
\text { akhir tahun: }\end{array}$ \\
\hline
\end{tabular}

Berikut adalah kebijakan batas kapitalisasi biaya pemeliharaan pada pemkot Semarang.

Tabel 3

Batas kapitalisasi belanja pemeliharaan Pemkot Semarang

\begin{tabular}{|l|l|}
\hline Akun & Batas kapitalisasi \\
\hline 1. Tanah & Lebih dari $15 \%$ \\
\hline $\begin{array}{l}\text { 2. Peralatan dan } \\
\text { mesin }\end{array}$ & Lebih dari $5 \%$ \\
\hline $\begin{array}{l}\text { 3. Gedung dan } \\
\text { Bangunan }\end{array}$ & Lebih dari $6 \%$ \\
\hline $\begin{array}{l}\text { 4. Jalan, Irigasi dan } \\
\text { Jaringan }\end{array}$ & Lebih dari $20 \%$ \\
\hline $\begin{array}{l}\text { 5. Aset Tetap } \\
\text { lainnya } \\
\text { Konstruksi Dalam } \\
\text { Pengerjaan }\end{array}$ & \\
\hline
\end{tabular}

Sedangkan kebijakan Penyisihan piutang pada Pemkot Semarang dikaji dengan analisa umur piutang.

\begin{tabular}{|l|l|}
\hline $\begin{array}{l}\text { Umur Piutang Melebihi } \\
\text { Jatuh Tempo Penyisihan }\end{array}$ & Penyisihan \\
\hline 1 bulan 1 hari s/d 3 bulan & $20 \%$ \\
\hline 3 bulan 1 hari s/d 6 bulan & $40 \%$ \\
\hline 6 bulan 1 hari s/d 9 bulan & $60 \%$ \\
\hline 9 bulan 1 hari s/d 1 tahun & $80 \%$ \\
\hline 1 tahun lebih & $100 \%$ \\
\hline
\end{tabular}

Sistem Informasi Akuntansi yang digunakan oleh pemkot Semarang adalah MySQL dalam penyusunan Laporan keuangannya. MySQL adalah sebuah perangkat lunak sistem manajemen basis data SQL (bahasa Inggris: database management system) atau DBMS yang multithread, multi-user, dengan sekitar 6 juta instalasi di seluruh dunia. MySQL AB membuat MySQL tersedia sebagai perangkat lunak gratis dibawah lisensi GNU General Public License (GPL). Implementasi akuntansi Akrual pada pemerintah kota Semarang dilakukan secara langsung.

\section{Implementasi Akuntansi Akrual Pada Pemerintah Kota Bandar Lampung}

Pemerintah Kota Bandar Lampung mulai menerapkan PP 71 tahun 2010 untuk penyusunan Laporan keuangan tahun 2013. Bagan akun standar yang di buat oleh pemerintah kota Bandar Lampung sudah sesuai dengan permendagri 64 tahun 2013. Pada Pemerintah Kota Bandar Lampung, pencatatan persediaan menggunakan Metode Fisik, disajikan sebesar:

1.Biaya perolehan apabila diperoleh dengan pembelian;

2.Biaya standar/Harga pokok produksi apabila diperoleh dengan memproduksi sendiri;

3. Nilai wajar, apabila diperoleh dengan cara lainnya seperti donasi/rampasan.

Sedangkan Piutang Diakui pada saat:

(1) Diterbitkan surat ketetapan; atau

(2) Telah diterbitkan surat penagihan dan telah dilaksanakan penagihan;

(3) Belum dilunasi sampai dengan akhir periode pelaporan

Tabel 4

Kebijakan Penyisihan Piutang

Pemkot Semarang
Piutang dicatat sebesar Nilai nominal yang belum dilunasi dari setiap tagihan yang 
ditetapkan. Piutang disajikan sebesar nilai bersih yang dapat direalisasikan (net realizable value), oleh karena itu, terhadap piutang yang diperkirakan tidak akan tertagih dilakukan penyisihan. Bila telah melalui masa jatuh tempo, piutang masih belum terbayarkan maka piutang tersebut harus disisihkan dalam bentuk Cadangan Kerugian Piutang. Penyisihan piutang tidak tertagih dilakukan melalui estimasi berdasarkan umur piutang (aging schedule). Piutang dalam aging schedule dibedakan menurut jenis piutang, baik dalam menetapkan umur maupun penentuan besaran yang akan disisihkan. Perhitungan cadangan kerugian piutang dilakukan dengan persentase tertentu dari total saldo, besaran penyisihan piutang sama dengan yang ditetapkan oleh pemerintah kota Semarang.

\section{Persediaan Diakui Pada Saat :}

1. potensi manfaat ekonomi masa depan diperoleh dan mempunyai nilai atau biaya yang dapat diukur dengan andal, dan

2. pada saat diterima atau hak kepemilikannya dan/ atau kepenguasaannya berpindah

Pencatatan Persediaan Menggunakan Metode Fisik, Disajikan Sebesar:

1. Biaya perolehan apabila diperoleh dengan pembelian;

2. Biaya standar/Harga pokok produksi apabila diperoleh dengan memproduksi sendiri;

3. Nilai wajar, apabila diperoleh dengan cara lainnya seperti donasi/rampasan.

Persediaan dinilai dengan menggunakan:

1. Metode FIFO (First In First Out), sehingga persediaan yang ada tinggal persediaan sisa pembelian akhir, kecuali Penilaian Persediaan obat menggunakan Metode FIFO dengan mempertimbangkan kadaluarsa;

2. Harga pembelian terakhir apabila setiap unit persediaan nilainya tidak material dan bermacam-macam jenis.

Aset lainnya adalah aset pemerintah selain aset lancar, investasi jangka panjang, aset tetap dan dana cadangan. Aset lainnya antara lain aset tak berwujud, kemitraan dengan pihak ketiga, kas yang dibatasi penggunaannya, dan aset lain-lain. Aset Tak berwujud (goodwill, hak paten, royaty dll)

Pengakuan Aset Tak Berwujud harus memenuhi kriteria sebagai berikut:

1. Kemungkinan besar diperkirakan manfaat ekonomi di masa datang yang diharapkan atau jasa potensial yang diakibatkan dari Aset Tak Berwujud tersebut akan mengalir kepada/dinikmati oleh entitas; dan

2. Biaya perolehan atau nilai wajarnya dapat diukur dengan andal

Pengukuran Aset Tak Berwujud diukur dengan harga perolehan. Terhadap Aset Tak Berwujud dilakukan amortisasi, kecuali atas Aset Tak Berwujud yang memiliki masa manfaat tak terbatas. Amortisasi dapat dikukan dengan berbagai metode seperti garis lurus, metode saldo menurun dan metode unit produksi.

Aset Lain-lain digunakan untuk mencatat aset lainnya yang tidak dapat dikelompokkan dalam aset tak berwujud, tagihan penjualan angsuran, tuntutan perbendaharaan, tuntutan ganti rugi, dan kemitraan dengan pihak ketiga

Aset tetap yang dimaksudkan untuk dihentikan dari penggunaan aktif pemerintah direklasifikasi ke dalam Aset Lain-lain. (rusak berat, usang, dan/atau aset tetap yang tidak digunakan karena sedang menunggu proses pemindahtanganan)

Pengakuan aset lain-lain diakui pada saat dihentikan dari penggunaan aktif pemerintah dan direklasifikasikan ke dalam aset lain-lain. Pengukuran aset tetap yang dimaksudkan untuk dihentikan dari penggunaan aktif pemerintah direklasifikasi ke dalam Aset Lainlain menurut nilai tercatatnya. Aset lain-lain yang berasal dari reklasifikasi aset tetap disusutkan mengikuti kebijakan penyusutan aset tetap. Aset Lain-lain disajikan di dalam kelompok Aset Lainnya dan diungkapkan secara memadai di dalam CaLK.

Aset tetap yang dimaksudkan untuk dihentikan dari penggunaan aktif pemerintah direklasifikasi ke dalam Aset Lain-lain. (rusak berat, usang, dan/atau aset tetap yang tidak digunakan karena sedang menunggu proses pemindahtanganan). Pengakuan aset lain-lain diakui pada saat dihentikan dari penggunaan aktif pemerintah dan direklasifikasikan ke dalam aset lain-lain 
Pengukuran aset tetap yang dimaksudkan untuk dihentikan dari penggunaan aktif pemerintah direklasifikasi ke dalam Aset Lainlain menurut nilai tercatatnya. Aset lain-lain yang berasal dari reklasifikasi aset tetap disusutkan mengikuti kebijakan penyusutan aset tetap.

Aset Lain-lain disajikan di dalam kelompok Aset Lainnya dan diungkapkan secara memadai di dalam CaLK.

\section{Pengakuan Kewajiban}

1. Kewajiban diakui pada saat:

2. Dana pinjaman diterima oleh pemerintah; atau

3. Dana pinjaman dikeluarkan oleh kreditur sesuai dengan kesepakatan pemerintah daerah; atau

4. Pada saat kewajiban timbul.

5. Kewajiban dapat timbul dari:

6. Transaksi dengan pertukaran (exchange transactions);

7. Transaksi tanpa pertukaran (nonexchange transactions), sesuai hukum yang berlaku dan kebijakan yang diterapkan, yang belum dibayar lunas sampai dengan saat tanggal pelaporan;

8. kejadian yang berkaitan dengan pemerintah (government-related events); dan

9. Kejadian yang diakui pemerintah (government-acknowledged events).

Kewajiban dicatat sebesar nilai nominal yang mencerminkan nilai kewajiban pemerintah daerah pada saat pertama kali transaksi berlangsung.

Ekuitas adalah kekayaan bersih pemerintah yang merupakan selisih antara aset dan kewajiban pemerintah pada tanggal laporan. Saldo Ekuitas berasal dari Ekuitas awal ditambah (dikurang) oleh Surplus/Defisit LO dan perubahan lainnya seperti koreksi nilai persediaan, selisih evaluasi Aset Tetap, dan lain-lain.

Ekuitas SAL digunakan untuk mencatat akun perantara dalam rangka penyusunan Laporan Realisasi Anggaran dan Laporan Perubahan SAL mencakup antara lain Estimasi Pendapatan, Estimasi Penerimaan
Pembiayaan, Apropriasi Belanja, Apropriasi Pengeluaran Pembiayaan, dan Estimasi Perubahan SAL, Surplus/Defisit - LRA.

Ekuitas untuk Dikonsolidasikan digunakan untuk mencatat reciprocal account untuk kepentingan konsolidasi, yang mencakup antara lain Rekening Koran PPKD.

Pendapatan-LO merupakan hak pemerintah daerah yang diakui sebagai penambah ekuitas dalam periode tahun anggaran yang bersangkutan dan tidak perlu dibayar kembali.

Pendapatan-LO diakui pada saat:

1. Timbulnya hak atas pendapatan. Kriteria ini dikenal juga dengan earned.

2. Pendapatan direalisasi, yaitu adanya aliran masuk sumber daya ekonomi baik sudah diterima pembayaran secara tunai (realized) maupun masih berupa piutang (realizable)

Pendapatan Non Operasional mencakup antara lain Surplus Penjualan Aset Nonlancar, Surplus Penyelesaian Kewajiban Jangka Panjang, Surplus dari Kegiatan Non Operasional Lainnya

3 (tiga) alternative pengakuan :

1) Pendapatan pajak yang didahului oleh penerbitan Surat Ketetapan. diakui ketika telah diterbitkan penetapan berupa Surat Ketetapan (SK) atas pendapatan terkait

2) Pendapatan pajak yang didahului dengan penghitungan sendiri oleh wajib pajak (self assessment) dan dilanjutkan dengan pembayaran oleh wajib pajak berdasarkan perhitungan tersebut. diakui ketika telah diterbitkan penetapan berupa Surat Ketetapan (SK) atas pendapatan terkait

3) Pendapatan retribusi yang pembayarannya diterima untuk memenuhi kewajiban dalam periode tahun berjalan diakui ketika pembayaran telah diterima.

Pendapatan-LO operasional non pertukaran, diukur sebesar aset yang diperoleh dari transaksi non pertukaran yang pada saat perolehan tersebut diukur dengan nilai wajar. Pendapatan-LO dari transaksi pertukaran diukur dengan menggunakan harga 
sebenarnya (actual price) yang diterima ataupun menjadi tagihan sesuai dengan perjanjian yang telah membentuk harga

Tabel 5

Perbedaan Kebijakan Pendapatan LRA dan Pendapatan LO Pemkot Bandar Lampung

\begin{tabular}{|c|c|}
\hline URAIAN & LRA (Anggaran) \\
\hline Pengakuan & $\begin{array}{l}\text { a. Diterima di Rekening Kas Umum } \\
\text { Daerah; atau } \\
\text { b. Diterima oleh SKPD; atau } \\
\text { c. Diterima entitas lain diluar pemerintah } \\
\text { daerah atas nama BUD. }\end{array}$ \\
\hline Pengukuran & $\begin{array}{l}\text { a. membukukan penerimaan bruto, dan } \\
\text { tidak mencatat jumlah netonya (setelah } \\
\text { dikompensasikan dengan } \\
\text { pengeluaran) } \\
\text { b. diukur dengan menggunakan nilai } \\
\text { nominal kas yang masuk ke kas } \\
\text { daerah dari sumber pendapatan } \\
\text { dengan menggunakan asas bruto } \\
\text { c. Dalam hal besaran pengurang } \\
\text { terhadap Pendapatan-LRA bruto } \\
\text { (biaya) bersifat variabel terhadap } \\
\text { pendapatan dimaksud dan tidak dapat } \\
\text { dianggarkan terlebih dahulu } \\
\text { dikarenakan proses belum selesai, } \\
\text { maka asas bruto dapat dikecualikan } \\
\text { d. Pengecualian azas bruto dapat terjadi } \\
\text { jika penerimaan kas dari pendapatan } \\
\text { tersebut lebih mencerminkan aktivitas } \\
\text { pihak lain dari pada pemerintah daerah } \\
\text { atau penerimaan kas tersebut berasal } \\
\text { dari transaksi yang perputarannya } \\
\text { cepat, volume transaksi banyak dan } \\
\text { jangka waktunya singkat }\end{array}$ \\
\hline
\end{tabular}

Beban diakui pada saat timbulnya kewajiban, terjadi konsumsi aset, atau terjadinya penurunan manfaat ekonomi atau potensi jasa/saat terjadinya peralihan hak dari pihak lain ke pemerintah tanpa diikuti keluarnya kas dari kas umum daerah.

\section{Pengakuan Beban PPKD}

\section{Beban bunga}

a. Pendapatan-LO operasional non pertukaran, diukur sebesar aset yang diperoleh dari transaksi non pertukaran yang pada saat perolehan tersebut diukur dengan nilai wajar

b. Pendapatan-LO dari transaksi pertukaran diukur dengan menggunakan harga sebenarnya (actual price) yang diterima ataupun menjadi tagihan sesuai dengan perjanjian yang telah membentuk harga
Beban bunga diakui saat bunga tersebut jatuh tempo untuk dibayarkan

2. Beban Subsidi

Beban subsidi diakui pada saat kewajiban pemerintah daerah untuk memberikan subsidi telah timbul.

3. Beban hibah

Pengakuan beban hibah sesuai NPHD dilakukan bersamaan dengan penyaluran

4. Beban Bantuan social

Pengakuan beban bantuan sosial dilakukan bersamaan dengan penyaluran

5. Beban penyisihan piutang 
Beban Penyisihan Piutang diakui saat akhir tahun.

6. Beban Transfer

Beban transfer diakui saat diterbitkan SP2D atau pada saat timbulnya kewajiban pemerintah daerah (jika terdapat dokumen yang memadai). Dalam hal pada akhir Tahun Anggaran terdapat pendapatan yang harus dibagihasilkan tetapi belum disalurkan dan sudah diketahui daerah yang berhak menerima, maka nilai tersebut dapat diakui sebagai beban.

\section{Pengakuan Beban SKPD}

1. Beban pegawai

Beban pegawai melalui mekanisme LS, diakui saat diterbitkan SP2D atau pada saat timbulnya kewajiban pemerintah daerah. Melalui GU/UP/TU $\rightarrow$ beban pegawai diakui ketika bukti pembayaran beban

2. Beban Barang

Beban barang diakui ketika bukti penerimaan barang atau Berita Acara Serah Terima ditandatangani. Dalam hal pada akhir tahun masih terdapat barang persediaan yang belum terpakai, maka dicatat sebagai pengurang beban

Beban dari transaksi non pertukaran diukur sebesar aset yang digunakan atau dikeluarkan yang pada saat perolehan tersebut diukur dengan nilai wajar. Beban dari transaksi pertukaran diukur dengan menggunakan harga sebenarnya (actual price) yang dibayarkan ataupun yang menjadi tagihan sesuai dengan perjanjian yang telah membentuk harga.

Untuk Penyusunan laporan keuangan pemerintah kota Semarang menggunakan Microsoft Excell. Berdasarkan hasil wawancara dengan Kabid Akuntansi dan pelaporan pemerintah kota Semarang alas an penggunaan Microsoft Excell dalam penyusunan laporan keuangan adalah lebih mudah di pahami dan lebih ekonomis.

Pemerintah Kota Bandar Lampung menggunakan metode implementasi bertahap, dimana Pemerintah Kota Bandar Lampung menyusun dua versi Laporan keuangan, baik berdasarkan PP 24 tahun 2005 maupun berdasarkan PP 71 tahun 2010. Dimana secara formal dan untuk tujuan pemeriksaan laporan Keuangan Oleh BPK Pemerintah Kota
Bandar Lampung masih menggunakan laporan keuangan berdasarkan PP 24 tahun 2005. Dalam Penyusunan Laporan keuangannya Pemerintah Kota Bandar Lampung menggunakan Microsoft Excel. Yang membedakan Implementasi Akuntansi Akrual antara Pemerintah Kota Bandar Lampung dengan Pemerintah Kota Semarang dan Tanggerang adalah, pengakuaan pendapatan LO sesuai dengan Kronologis transaksi karena Pemerintah Kota Bandar Lampung sudah melakukan sesus ulang terhadap objek Pajak.

\section{KESIMPULAN}

Berdasarkan pembahasan masalah yang diuraikan di atas, maka dapat ditarik kesimpulan sebagai berikut.

2. Pemerintah Kota semarang mengimplementasi Akuntansi Akrual sejak tahun 2005. Bagan Akun Standar yang disusun dan kebijakan akuntansi yang ditetapkan Oleh Pemerintah Kota Semarang sudah sesuai dengan peraturan berlaku. Untuk penyusunan Laporan keuangan, Pemerintah Kota Semarang menggunakan MySQL.

3. Pemerintah kota Bandar Lampung mulai menerapkan Akuntansi akrual sejak tahun 2013, secara bertahap dimana secara formal masih menggunakan PP 24 tahun 2005 dalam penyusunan Laporan Keuangannya. Secara informal mereka juga menyusun Laporan Keuangan berdasarkan PP 71 tahun 2010. Untuk penyusunan Laporan keuangan, Pemerintah Kota Bandar Lampung menggunakan Microsoft Excell. Bagan Akun Standar yang disusun dan kebijakan akuntansi yang ditetapkan Oleh Pemerintah Kota Semarang sudah sesuai dengan peraturan berlaku.

\section{DAFTAR REFERENSI}

Kebijakan Akuntansi Pemerintah Kota Semarang, 2013

Kebijakan Akuntansi pemerintah Kota Bandar Lampung, 2015

Oktaviani et al., Overview Implementasi Accrual-Based Budgeting pada Entitas Pemerintahan, E-Journal Ekonomi Bisnis dan Akuntansi 2014, Volume 1 (1): 56-66

Suara Merdeka.com, 03 September 2012, Pemkot Pelopori Penggunaan Akuntansi 
Implementasi Akuntansi Berbasis Akrual Pada Pemerintah Daerah

(Studi Pada Pemerintah Kota Semarang Dan Pemerintah Kota Bandar Lampung)

Berbasis Akrual, diunduh tanggal 1 April 2013

Undang-Undang No. 17 Tahun 2003 tentang Keuangan Negara

Undang-Undang No.1 Tahun 2004 tentang Perbendaharaan Negara

Undang-Undang No.32 Tahun 2004 tentang Pemerintah Daerah

Peraturan Pemerintah No.24 Tahun 2005 tentang Standar Akuntansi Pemerintah

Peraturan Pemerintah No. 71 Tahun 2010 tentang Standar Akuntansi Pemerintah 